\title{
INFLUENCE OF TERRORISM RISK ON FOREIGN TOURISM DECISIONS
}

By: Sevil F. Sönmez, Alan R. Graefe

Sönmez, S. and A.R. Graefe (1998). Influence of Terrorism Risk on Foreign Tourism Decisions. Annals of Tourism Research, 25(1):112-144.

Made available courtesy of Elsevier: http://www.elsevier.com/

*** Note: Figures may be missing from this format of the document

\begin{abstract}
:
This study explored relationships between selected factors and several key stages of the international vacation tourism decision-making process. A theoretical framework of vacation decisions involving terrorism risk served as the foundation for the analysis. Eight independent variables were examined, including international travel experience, risk perception level, international travel attitude, age, gender, education, income and presence of children in household. Dependent variables were three key stages of the decision-making process, including the general decision to travel internationally versus domestically, the extent of information search and concern for safety in evaluating destination alternatives. A mail survey of international tourists achieved a $48 \%$ response rate. Non-response bias was tested with telephone interviews. Data were analyzed using multiple and simple regression. International attitude, risk perception level and income were found to directly influence international vacation destination choice. Touristic experience and education were indirect influences.
\end{abstract}

Keywords: international vacation tourism, terrorism, political instability risk, tourist decision-making, destination choice.

Resume: L'influence du risque de terrorisme sur les decisions du tourisme l'etranger. On a examine certains facteurs et \&apes du processus de decisions dans le tourisme international. Un cadre theorique ou le terrorisme entre en consideration a servi comme base de l'analyse. Les variables independantes comprenaient experience, perception des risques et attitude. Les variables dependantes comprenaient la tendance aux voyages internationaux, l'etendue de la recherche d'information et le souci de securite dans l'evaluation des destinations. Une enquete par courrier a obtenu 48 pour cent de reponses. On a teste la non-reponse par des interviews telephoniques. En utilisant des regressions simple et multiple, on a trouve que l'attitude internationale, la perception des risques et les revenus influencent directement le choix de destination internationale. L'experience touristique et l'education etaient des influences indirectes.

Mots-cies: tourisme international, terrorisme, decisions, choix de destination.

\section{Article:}

\section{INTRODUCTION}

Despite tourism s economic strength, terrorism and political turmoil present major challenges to the industry. Terrorism began to make headlines around the world in the 70s and reached its peak in the mid-80s (Table 1). Tourism figures following the height of terrorist activity illustrate travelers' serious reaction to potential risk and substantiate the statement "overreaction increases the impact and importance of terrorist events" (Richter and Waugh 1986:235). More than six million Americans visited Europe in 1985. Seven million were projected to go the following year; however, this flow to Europe decreased by $30 \%$ in 1986. Nearly two million Americans changed their foreign travel plans in 1986, following the previous year's terrorism and the US-Libya military confrontation (Edge11 1990; Richter and Waugh 1986).

Predictably, shifts in touristic plans seriously curtailed revenues for many countries. The threat of terrorism was blamed, by the World Tourism Organization (WTO), for $\$ 105$ billion in lost (unearned) tourism receipts in 1985. Mediterranean countries suffered when bookings declined by $50 \%$ during the same period and bookings dropped by 65\% in Egypt when American visitors began to cancel their plans. According to a Gallup Poll conducted for Newsweek in April 1986, 79\% of Americans said they would reject an opportunity to travel 
overseas because of the threat of terrorism. A survey of 205 travel agents found nearly $48 \%$ of cancellations were due to terrorist attacks (Lehrman 1986). A study of hotel occupancy rates found that, after repeated terrorist attacks in 1985, hotels in Rome experienced a drastic reduction of nearly $60 \%$ among their American guests (Hurley 1988).

Table 1. Highly Publicized Terrorist Attacks during the Peak of Terrorism

\begin{tabular}{ll}
\hline Year & \multicolumn{1}{c}{ Incident } \\
\hline 1972 & Terrorist attack during Olympic Games (Munich) \\
1985 & TWA flight 847 hijacking (Athens/Rome) \\
1985 & Air India 182 from Toronto bombed (over North Atlantic) (329 dead) \\
1985 & Tokyo's Narita Airport bombed (Japan) \\
1985 & Frankfurt's Rhein-Main Airport bombed (West Germany) \\
1985 & Egyptian jetliner hijacked (Malta) (55 dead) \\
1985 & TWA 814 out of Athens, hijacked to Beirut \\
1985 & Air India 747 bomb explosion (en route from Montreal to Tokyo) (1 dead, \\
& 43 hostages for 16 days) \\
1985 & TWA, British Airways offices bombed (Madrid/ Rome) \\
1985 & Athens hotel bombed (Greece) \\
1985 & Cafe bombed (Rome) \\
1985 & British Airways office bombed (Rome) \\
1985 & Achille Lauro cruise ship hijacked (Mediterranean) (1 dead) \\
1985 & Leonardo da Vinci (Rome) airport and Schwechat airport (Vienna) machine \\
& gunned (18 dead, 100 injured) \\
1986 & TWA 840 en route from Athens to Rome bombed (4 dead) \\
1986 & Discotheque bomb explosion (West Berlin) \\
1986 & Pan Am hijacking (Karachi) (20 dead) \\
1986 & Iraqi Airways Boeing hijacked (60 dead) \\
1986 & Air Lanka Tristar bombed at Colombo airport (en route to Maldives) (17 \\
1986 & Cead) \\
1987 & Bombing of Korean Air 858 (115 dead) \\
1988 & PanAm 103 bombed over Lockerbie, Scotland (270 dead) \\
\hline
\end{tabular}

Sources: Fletcher 1993; Mickolus 1980; The Economist 1990.

Faced with an unmistakable crisis, the tourism industry reacted with recovery marketing efforts. To encourage travel, airlines began promotional campaigns and generous incentives, such as 2-for-1 ticket offers, free round trip companion tickets and free car rentals. Hotels advertised rate reductions ranging from $25 \%$ to $50 \%$ (Wall 1996). Cruiseships repositioned their routes and offered packages to stimulate tourism. In addition, some travel agencies boycotted European countries that demonstrated a tolerance for terrorism. The combination of terrorist activity and heightened marketing efforts motivated a massive realignment of travel flows in the summer of 1986 (D'Amore and Anuza 1986; Wall 1996).

Regardless of the number of occurrences, terrorism continues to capture world attention in the 90s. Terrorist acts (such as those listed in Table 2) exacerbate public perception of danger in the world in general and at some destinations in particular. Despite fluctuating numbers of attacks, terrorism continues to be a force with which the industry must reckon. Repeated terrorist occurrences in the summer of 1996 have once again brought the subject to the forefront.

According to the US Department of State, while the number of terrorist incidents has declined since the 80s, their lethality has increased. Disheartening forecasts of terrorism portray it doubling in volume while spreading geographically (Jenkins 1988). The most frightening predictions of terrorism involve the use of nuclear materials to make weapons of mass destruction. It has also been suggested that the public will witness more terrorism in the future than ever before, as a result of the news media's improved ability and willingness to cover it (Jenkins 1988). On a more positive note, the fight against international terrorism has increased cooperation among nations in counter-terrorism activities, law enforcement, and intelligence gathering (US Department of State 1996). 
Political instability describes a situation "in which conditions and mechanisms of governance and rule are challenged as to their political legitimacy by elements operating from outside of the normal operations of the political system" (Hall and O'Sullivan 1996:106). At first glance, political instability and terrorism may appear unrelated. Closer examination, however, brings into focus certain situations which demonstrate otherwise. Terrorism can be the manifestation of a political crisis; examples of countries where terrorist activity has resulted from political turmoil include Lebanon, Italy, and the former West Germany (Wieviorka 1994). In fact, terrorism has been identified as a dimension of political instability—along with international and civil wars, coups, riots, social unrest, and strikes (Hall and O'Sullivan 1996:109). Political instability may not be as blatant as terrorism; it does, however, present just as formidable a barrier to international tourism. Continuous media coverage of political rebellion, military coups, or regional wars can deter tourists from choosing to travel to specific destinations or even entire regions.

Table 2. Recent Terrorist Incidents Involving Tourists

\begin{tabular}{|c|c|c|}
\hline Year & Country & Incident \\
\hline \multicolumn{3}{|l|}{1993} \\
\hline $2 / 4$ & Egypt & $\begin{array}{l}\text { Molotov cocktail bomb thrown at tour bus as South Korean } \\
\text { passengers waited to embark at a hotel outside Cairo }\end{array}$ \\
\hline $2 / 26$ & USA & $\begin{array}{l}\text { A massive van bomb exploded in an underground parking } \\
\text { garage below New York's World Trade Center, killing } 6 \text { and } \\
\text { injuring } 1,000\end{array}$ \\
\hline $6 / 8$ & Egypt & $\begin{array}{l}\text { A bomb exploded underneath an overpass as a tour bus } \\
\text { traveled toward Giza pyramids, killing } 2 \text { Egyptians and } \\
\text { injuring } 6 \text { British, } 3 \text { Syrians, and } 3 \text { others }\end{array}$ \\
\hline $6 / 27$ & Turkey & $\begin{array}{l}\text { Terrorists from the Kurdistan Workers Party (PKK), a } \\
\text { separatist group, threw hand grenades at various hotels and } \\
\text { restaurants frequented by tourists in Mediterranean resort } \\
\text { areas, injuring } 12 \text { foreigners and } 16 \text { Turks }\end{array}$ \\
\hline $7 / 7$ & Peru & $\begin{array}{l}\text { Bodies of } 2 \text { European tourists were discovered by police in a } \\
\text { region of Ayachucho, contested by Sendero Luminoso } \\
\text { terrorists }\end{array}$ \\
\hline $7 / 5$ & Turkey & $\begin{array}{l}\text { In } 8 \text { separate incidents (beginning in July and ending in } \\
\text { October), the PKK kidnapped } 19 \text { Western tourists traveling } \\
\text { in southeastern Turkey, hostages were not released for } \\
\text { several weeks }\end{array}$ \\
\hline $10 / 25$ & Nigeria & $\begin{array}{l}4 \text { members of a Nigerian dissident group hijacked a Nigerian } \\
\text { Airways Airbus } 310 \text { airliner with } 150 \text { passengers and crew } \\
\text { after it took off from Lagos. Three days later the aircraft } \\
\text { was stormed by Nigerian police }\end{array}$ \\
\hline $10 / 25$ & Peru & $\begin{array}{l}\text { A large bomb exploded underneath a minibus in the parking } \\
\text { lot near the departure terminal at Lima's international } \\
\text { airport, killing the driver and injuring } 20\end{array}$ \\
\hline $12 / 27$ & Egypt & $\begin{array}{l}7 \text { Austrian tourists and } 8 \text { Egyptians were wounded when a } \\
\text { tour bus was fired at by terrorists in Cairo }\end{array}$ \\
\hline \multicolumn{3}{|l|}{1994} \\
\hline $2 / 19$ & Egypt & $\begin{array}{l}\text { A passenger train was fired upon, wounding } 2 \text { women (Polish } \\
\text { and Thai) and } 2 \text { Egyptian citizens }\end{array}$ \\
\hline $2 / 23$ & Egypt & $\begin{array}{l}\text { A bomb exploded aboard a passenger train in Asyut, injuring } \\
6 \text { foreign tourists }\end{array}$ \\
\hline $3 / 4$ & Egypt & $\begin{array}{l}\text { Gunmen opened fire at a Nile cruise ship, wounding a } \\
\text { German tourist }\end{array}$ \\
\hline $3 / 9-13$ & UK & $\begin{array}{l}\text { The Provisional Irish Republican Army fired mortars at } \\
\text { London's Heathrow International Airport in three separate } \\
\text { attacks. No injuries were recorded due to the failure of the } \\
\text { mortars to detonate }\end{array}$ \\
\hline $4 / 27$ & South Africa & $\begin{array}{l}\text { A car bomb exploded at Jan Smuts Airport in Johannesburg, } \\
\text { injuring } 16 \text { persons }\end{array}$ \\
\hline $7 / 26$ & Cambodia & $\begin{array}{l}\text { The Khmer Rouge attacked a train traveling in Kompong } \\
\text { Trach and kidnapped several passengers including an } \\
\text { Australian, a Briton and a Frenchman }\end{array}$ \\
\hline $8 / 8$ & Turkey & $\begin{array}{l}\text { The PKK kidnapped } 2 \text { Finnish tourists stating they did not } \\
\text { have "entry visas for Kurdistan", the tourists were released } \\
\text { unharmed after } 22 \text { days }\end{array}$ \\
\hline $12 / 24$ & Algeria & $\begin{array}{l}\text { Members of the Armed Islamic Group hijacked an Air } \\
\text { France flight to Marseille, France, } 3 \text { hostages were killed by } \\
\text { terrorists, all } 4 \text { of whom were killed by a French antiterrorist } \\
\text { unit }\end{array}$ \\
\hline
\end{tabular}


Table 2. Continued

\begin{tabular}{|c|c|c|}
\hline Year & Country & Incident \\
\hline \multicolumn{3}{|l|}{1995} \\
\hline $1 / 12$ & Egypt & $\begin{array}{l}\text { Suspected members of al-Gama'at al-Islamiyya opened fire } \\
\text { on a passenger train carrying tourists, } 6 \text { passengers, } \\
\text { including } 2 \text { Argentine, tourists were hurt }\end{array}$ \\
\hline $1 / 15$ & Cambodia & $\begin{array}{l}\text { US tourist and a tour guide were killed when Khmer Rouge } \\
\text { rebels attacked a sightseeing convoy. }\end{array}$ \\
\hline $5 / 23$ & Peru & $\begin{array}{l}\text { Members of Sendero Luminoso detonated a } 50 \mathrm{~kg} \text { car bomb } \\
\text { in front of the Maria Angola Hotel near Lima, killing } 3 \text { hotel } \\
\text { employees and injuring } 30\end{array}$ \\
\hline $7 / 4-8$ & India & $\begin{array}{l}6 \text { international tourists were taken hostage in Kashmir by } \\
\text { a militant group, } 1 \text { escaped, } 1 \text { was decapitated }\end{array}$ \\
\hline $7 / 13$ & Turkey & $\begin{array}{l}\text { PKK abducted a Japanese tourist near Siirt and released } \\
\text { him unharmed } 4 \text { days later }\end{array}$ \\
\hline $10 / 9$ & USA & $\begin{array}{l}\text { A group named Sons of the Gestapo claimed responsibility } \\
\text { for derailing an Amtrak passenger train in Arizona's desert, } \\
\text { killing } 1 \text { railroad worker and injuring } 98 \text { passengers and } \\
\text { crew }\end{array}$ \\
\hline \multicolumn{3}{|r|}{ (1) } \\
\hline $4 / 18$ & Egypt & $\begin{array}{l}\text { Three gunmen attacked tour bus with Greek tourists in } \\
\text { front of Cairo hotel, killing } 18\end{array}$ \\
\hline $7 / 17$ & USA & $\begin{array}{l}\text { TWA800 en route from New York's JFK Airport to Paris } \\
\text { exploded over southern coast of Long Island, killing } 230 \\
\text { passengers and crew (still under investigation at the time } \\
\text { of writing this article) }\end{array}$ \\
\hline $7 / 22$ & Pakistan & $\begin{array}{l}\text { Lahore International Airport bombed, killing 4, wounding } \\
68\end{array}$ \\
\hline $7 / 22$ & USA & $\begin{array}{l}\text { Pipe bomb found on tarmac at Chicago's O'Hare } \\
\text { International Airport (it was detonated without anyone } \\
\text { getting hurt) }\end{array}$ \\
\hline $7 / 26$ & Spain & $\begin{array}{l}\text { Iberian Airlines } 6621 \text { carrying } 232 \text { passengers (en route } \\
\text { from Madrid to Havana, Cuba) hijacked to Miami } \\
\text { International Airport with the threat of a bomb on board } \\
\text { (none hurt) }\end{array}$ \\
\hline $8 / 3$ & USA & $\begin{array}{l}\text { Pipe bomb exploded at Centennial Olympic Park in Atlanta } \\
\text { during the } 1996 \text { Olympics, killing } 1 \text {, causing a second death } \\
\text { by heart attack, injuring } 111\end{array}$ \\
\hline
\end{tabular}

Sources: Fletcher (1993); US Department of State (1994, 1995, 1996).

In 1991, the industry was once again reminded of its vulnerability to political turbulence. International tourism was inhibited throughout the Persian Gulf War. During Operation Desert Storm, 275 terrorist incidents were recorded. At the time, the perceived dangers of going anywhere near the Middle East discouraged travel (Abu Fadil 1992; Hollier 1991; US Department of State 1992). The North American tourism industry experienced serious problems in both inbound and outbound travel (US House of Representatives 1991; WTO 1991). As a result, tourism in the Middle Eastern countries experienced corresponding difficulties, despite probable discrepancies between travelers' perceptions of risk and actual danger to them. Egypt, Israel, Jordan, Turkey, and the United Arab Emirates are among those which recorded particularly sharp drops in tourist arrivals. Other well-publicized recent occurrences of political conflict include the war in the Balkans following the disintegration of Yugoslavia; conflicts in Burundi, Haiti, Rwanda, Somalia, and South Africa; the ongoing Palestinian-Israeli strife in the Middle East; and friction between India and Pakistan.

As the new millennium approaches, political turmoil and terrorism continue to compete for headlines with other issues of global interest. The intent of the study reported here was to explore the relationship between terrorism/political turmoil and international touristic decisions. More specifically, the study investigated impacts of individuals' past international experience; attitude toward international travel; level of risk perception; and their traveler personality type on three key stages of the international travel decision-making process. The key stages included the decision to visit a foreign country rather than a domestic destination, the 
amount of information search undertaken prior to actual travel, and the importance of safety during the evaluation of destination alternatives. The study also examined the influence of demographic factors on the three key decision stages.

\section{TERRORISM AND TOURISM}

Terrorism is an enigmatic and compelling phenomenon which draws abundant intellectual attention. In the hope of understanding and controlling terrorism, government and academic communities have exerted significant effort toward its study (Hacker 1978; May 1974; Poland 1988; Schmid and deGraaf 1982; Thornton 1968; Wilkinson 1979). The topic is so fraught with conceptual problems, that a universally accepted definition of terrorism does not exist (Poland 1988; Toman 1991; Schmid and Jongman 1988). The often quoted cliche "one person's terrorist is another person's freedom fighter" succinctly portrays varying viewpoints and definitional problems (Crenshaw 1989; Jenkins 1987, 1988; Poland 1988). In Patterns of Global Terrorism, an annual report of terrorist activity published by the US Department of State (1990, 1991, 1992, 1993, 1994), terrorism is defined as "premeditated, politically motivated violence perpetrated against civilians and unarmed military personnel by subnational groups ... usually intended to influence an audience" and international terrorism as "involving citizens or the territory of more than one country"(US Department of State 1996:3).

The escalation of terrorism, since the 70s, has been linked to mass communications (Alexander 1977; Sandler and Lapan 1988; Schmid and deGraaf 1982). Researchers point out that communication satellites are able to provide terrorists with instantaneous access to a global audience. Karber first proposed the communication dimension in conceptualizing terrorism, when he wrote "as a symbolic act, terrorism can be analyzed much like other mediums of communication" (Karber 1971:9). Karber's theory outlines four basic components of the communication process within the context of terrorism: transmitter of message (terrorist), intended recipient of message (target of terrorist's message), message (terrorist act involving individual or institutional victims), and feedback (reaction of the recipient). The theory can be presented in a context familiar to most:

By hijacking a passenger airline, terrorists initiate communication. The target of their message is likely to be a large and usually removed audience, such as the government the terrorists are protesting. The travelers on the plane and the hijacking itself represent the message which may involve certain demands. The acquiescence of the government to those demands represent the feedback required by the terrorists to confirm successful communication.

The 1972 Palestinian attack during the Munich Olympic Games, which reached a global audience of nearly 800 million viewers - and left 11 Israeli athletes dead-introduced the world to the plight of the Palestinians living in Israeli-occupied territories. The attack has been cited as a clear success in terms of securing media attention (Schmid and deGraaf 1982), a catalyst that turned terrorism into a cost-effective tool of communication, and a style of communication which became a "legitimate" method of intimidation.

\section{Tourism, Terrorism, and Political Turmoil}

"International terrorism crosses national borders, targets citizens of many nations and exploits technology of international travel and communications" (Schlagheck 1988:119). The simple fact that a modified version of this description can also be applied to international tourism, weakens intuitive objections to a relationship between the two phenomena. Until fairly recently, scholarly attention given to the relationship between tourism and politically motivated violence did not match the topic's significance. Since the 80s, scholars from diverse disciplines have examined the relationship between terrorism and tourism (Richter 1989; Richter and Waugh 1986), the economic impacts of terrorism (Enders and Sandler 1991; Enders, Sandler and Parise 1992), implications for tourism marketing (Brady and Widdows 1988; Buckley and Klemm 1993; Conant et al. 1988; D'Amore and Anuza 1986; Hollier 1991; Hurley 1988; Lehrman 1986; Sonmez 1994), and the impacts of political instability or war on tourism (Gartner and Shen 1992; Hall 1994; Mansfeld and Kliot 1996; Mihali 1996; Pitts 1996; Richter 1980, 1983; Schwartz 1991; Scott 1988; Sharpley and Sharpley 1995; Smith 1996;

Teye 1986, 1988). 
Several theoretical studies offer valuable insight and help advance understanding of the unique relationship between terrorism and tourism (Aziz 1995; Richter 1983; Richter and Waugh 1986; Wahab 1995). Richter compares peaceful travel between countries to diplomatic relations to explain the nature of the relationship and suggests that travelers might be targeted for violent attacks because they are perceived as ambassadors for their countries, as well as "soft" targets. When tourists are victimized, the situation is instantly magnified by the media and the political conflict between terrorists and their establishment is transferred to a much wider scale of international attention. The tourist's country of origin becomes involved in the situation and the subsequent involvement of other countries intensifies the pressure on the government that the terrorists are sending a message to. The widespread media attention focused on the terrorists' political views confirms the usefulness of tourists to terrorists (Richter 1983).

The literature also suggests that mass tourism itself can be a political issue. In some situations tourism can "spawn divisive conflicts among proponents and opponents of tourism development" (Richter 1983:18-19) and in others, socioeconomic, cultural, and communication gaps separating locals from tourists can create resentment and incite violence (Aziz 1995; Lea 1996; Wahab 1995). Richter (1983) suggests that tourism styles and itineraries might be viewed, by some, as representing ideological values, class behavior, and political culture of both tourists and their countries of origin. According to Ryan (1993) tourism symbolizes capitalism and state-sponsored tourism represents government to many people, so that an attack on tourism symbolizes an attack on the government terrorists oppose. Resentment toward tourism can thus lead to dangerous expressions of such feelings and even result in the victimization of tourists. In addition, because tourism represents a significant economic activity, terrorist attacks on tourists are effective tools for obtaining resources from or gaining political advantages over government officials (Richter and Waugh 1986).

Studies involving analyses of tourist visitation, expenditure figures, and acts of political violence lead to the unsurprising conclusion that terrorism, political instability, and regional war curtail tourism (Bar-On 1996; Brady and Widdows 1988; Hurley 1988; Tremblay 1989; Enders and Sandler 1991; Enders, Sandler and Parise 1992; Mihalie' 1996; Pitts 1996). The literature also confirms a definite substitution effect among destinations when terrorism or political turmoil risk is evident ( $\mathrm{Gu}$ and Martin 1992; Mansfeld and Kliot 1996) and suggests that tourists' nationality and level of previous experience influences their reactions to terrorism (Cook and McCleary 1983; D'Amore and Anuza 1986; Hurley 1988; Tremblay 1989; Wall 1996).

A recent surge in academic activity focusing on tourists' safety has been compiled by Pizam and Mansfeld (1996). While their compilation and other contributions to the topic shed light on the tourism industry's predicament resulting from terrorism, political instability, and war, too many authors have echoed each other in reviewing the well-documented incidents of terrorism and political conflict. Theoretical explanations of the topic at hand have elevated the issue to prominence; however, there is an indisputable need for more empirical research which promises to help identify solutions and minimize impacts of terrorism and political turmoil on the tourism industry. The organization of several recent conferences - each articulating research needsprovides the most salient indication of this growing awareness.

The first research conference on tourism security and risks (titled Talk at the Top: International Conference on Tourism Security and Risk) organized by Mid Sweden University, was held in 1995 in Sweden. Attendees from 20 countries - including researchers, tourism industry representatives, international organizations, and media members-discussed the topic on a global scale. The gathering was an important step in creating much needed awareness about tourism safety and security issues (Johansson and Nyberg 1996). Delegates indicated an "urgent need for improved global tourism related risk research, importance of the media in travel and tourism safety and security and need for local networks for visitor and resident safety and security" (Mid Sweden University 1995). Recommendations for the formation of a documentation and research center on travel security and risks led to the establishment of the Centre for Tourism Security and Risks (inaugurated in 1995 Ostersund). Four months later, the White House conference on tourism helped to explicate safety concerns about travelers. Most issues, however, gravitated around crime and natural disasters. Participants formulated numerous objectives to address important industry issues in the coming years. A particularly relevant one was 
"to mobilize the industry to respond to concerns about traveler safety and security through community partnerships and disaster preparedness programs" (National Travel and Tourism Strategy, 1995:30).

The War, Terrorism, Tourism: Times of Crisis and Recovery conference (September 25-27, 1997, Croatia), organized by the Institute for Tourism at Zagreb and the Faculty of Economics at the University of Zagreb, provided a forum for the tourism industry and the scholarly community to discuss strategies for recovery from tourism crises resulting from terrorism, political strife, and crime. The momentum created by these types of activities and exchange of ideas can hopefully be maintained until pragmatic solutions are found to help the tourism industry deal with crises resulting from terrorism and political instability.

\section{Risky Decisions}

Tourists may be justified in expecting some degree of protection by governments and the industry. Ultimately, however, individuals are responsible for their own decisions and actions. The introduction of risk into touristic decisions has the potential to disrupt routine decision-making. It is intuitively logical for potential tourists to compare destination alternatives according to perceived benefits and costs. In addition to typical vacation expenses (i.e., transportation, accommodation, food, entertainment), they can incur psychological, social, and time costs (Evans and Berman 1992). Another cost, particularly international, involves risks associated with the trip such as sickness, accident, crime, or terrorism - tourism can involve varying degrees of risk, from simple disappointment to serious injury, even death (Enders and Sandler 1991; Enders, Sandler and Parise 1992). It is reasonable to believe that the threat of terrorism at a particular destination will cause it to be perceived as more costly than a safer destination. Another assumption is that if the destination choice is narrowed down to two alternatives which promise similar benefits, the less costly one —one that is safe from threat—is likely to be chosen.

Despite their low probability, risks carrying high costs - such as terrorism - appear to provoke serious consumer reaction (Richter and Waugh 1986). For example, in 1985, 28 million Americans went abroad and 162 were either killed or injured as a result of terrorism, which indicates a $.00058 \%$ probability of being targeted (The Economist 1986a,b). As a result of terrorist activity in 1985, 1.8 million Americans changed their foreign plans the following year (Edge11 1990; Richter and Waugh 1986). Although risk can be an important element of decision-making, the function risk in general or terrorism risk in particular, it has received surprisingly little research attention and only recently at that (Cook and McCleary 1983; Crompton 1992; Mansfeld 1992; Roehl and Fesenmaier 1992; Um and Crompton 1990). Risks have mostly been treated as an issue of facilitators versus inhibitors or constraints. For example, time, budget, and physical distance have been identified as important constraints potential tourists use to discriminate between destination alternatives (Cook and McCleary 1983). Crompton (1977) suggested that destination choice is made after constraints (i.e., time, money) are weighed against destination image. vanRaaij and Francken (1984) added that decisions are made by weighing constraints against current economic situations. According to their premise, tourists might choose less expensive options or decide against travel during economic difficulty. It is likely for perceptions of crime, terrorism, or health risk to cause similar behavior. This idea is supported by Crompton's (1992) assertion that destinations perceived as too high risk, due to situational constraints or barriers, may become undesirable.

Potential tourists are likely to narrow down complex perceptions of destination attributes into simply facilitators ("beliefs about destination attributes which help to satisfy potential tourists' specific motives") and inhibitors ("attributes which are not congruent with motives") and eliminate destination alternatives from their consideration set by pondering the impacts of those inhibitors and facilitators (Um and Crompton 1990, 1992:19). Facilitators were found to exert greater influence in the earlier stages of decision-making, whereas inhibitors had more influence in later stages when the process (or outcome) becomes more serious (Um and Crompton 1992). This is demonstrated by the cancellation of plans to travel to a destination which has experienced terrorism or political problems after the vacation is booked. It also helps to explain why nearly 2 million Americans changed their international plans in 1986. 
In a study exploring the relationship between risk perceptions and leisure tourism, destination choice was found to become risky when the decision's consequences are uncertain or some outcomes are more desirable than others; and information search behavior was identified as a common risk reduction strategy (Roehl and Fesenmaier 1992). Of the seven types of risk identified in consumer behavior literature (Schiffman and Kanuk 1991), financial, psychological, satisfaction, and time risks were found to be most often associated with tourism. Roehl and Fesenmaier (1992) suggested that personality traits are used in explaining individuals' risk taking tendencies and this lends support to the tourist personality continuum developed by Plog (1974) which classified travelers into psychocentric (risk averse) and allocentric (risk taking) personality types. According to Roehl and Fesenmaier (1992) situational factors and types of risk perceived determine how potential travelers respond to risky situations.

To recap — when the consequences of a travel decision are uncertain, that decision is perceived as risky. Decision-makers proceed by comparing the benefits and costs of destination choices in order to select the one that promises the most benefits for the least cost. The costliest (or riskiest) destinations are likely to become undesirable and eliminated from the selection process. Potential tourists can eliminate part of the perceived risk by acquiring more information about destination alternatives; however, individuals' risk-taking tendencies and their style of response to risky situations are determined by personality traits, types of risk perceived, and situational factors.

\section{Theoretical Framework of the Study}

Decision-making models (consumer and tourist) and theories of risky decision-making comprise the foundation of this study. Several paradigms of decision-making were integrated, then adjusted, to reflect decisions involving terrorism and/or political instability risks. Expected utility theory is based on individuals' expectation of the overall usefulness of a prospect, its promise to increase existing resources, and their aversion to risk (Kahneman and Tversky 1979). Its inadequacy as a descriptive model of choice under risk has inspired the development of other theories, such as protection motivation theory (Rogers 1975), catastrophe theory (Svyantek, Deshon and Siler 1991), information integration theory (Anderson 1981, 1982) and prospect theory (Kahneman and Tversky 1979); two of which provide theoretical support for this study.

Prospect theory proposes that risky decision-making occurs in two stages: prospects are narrowed down to several alternatives and evaluated before the best option is selected (those considered undesirable are eliminated). When the theory is applied to touristic decisions involving terrorism risk, prospects are represented by potential destinations. The two-stage process involves evaluating destination alternatives according to safety from terrorism threat before choosing one and eliminating risky others. According to the theory, individuals' perceptions of risk influence the attractiveness of prospects being evaluated. Choices involving gains indicate a risk averse personality whereas choices involving losses indicate risk-seeking behavior. Risk averse individuals (i.e., psychocentrics) are likely to choose destinations perceived as safe, whereas risk seekers (i.e., allocentrics) are likely to show less concern about choosing destinations based on safety factors. The "framing effect", which occurs primarily in situations with time constraints and causes equivalent outcomes to appear as gains or losses, introduced the concept of "context" in which decision-makers evaluate alternatives (Tversky and Kahneman 1981, 1986). Because the framing effect generates a more extreme response to possible losses than that to possible gains by individuals, potential tourists are likely to choose the prospect perceived as less dangerous. Exposure to media coverage and negative word-of-mouth regarding terrorist threat can create the framing effect by causing one of two equally safe or dangerous destinations to appear safer or more dangerous than the other.

Information integration theory (IIT) was developed to explain the risk element in consumer decisions (Anderson 1981, 1982) but it can also be applied to decisions involving terrorism risk. Anderson proposed that consumers form psychophysical and value judgments according to complex decision-making steps that include need awareness, information search, evaluation of alternatives, and choice. Psychophysical judgements refer to subjective perceptions of physical reality (similar to potential tourists' attitudes toward a destination) and value judgements refer to the way consumers rank products or services by their attributes to form an overall image (in the process of forming a destination image, tourists may rank different destinations by weighing their costs and 
benefits). Impressions, evaluations, and judgments already formed of products or services (or destinations) under consideration may change if additional alternatives are added to the evaluation (an acquaintance might recommend a destination not previously considered); or new information with the potential of changing the consideration set is learned (such as recent terrorist activity at or near the destination being considered); or as a result of new information, prior to the final choice, consumers' perceptions of an alternative change (by media coverage of a political uprising or terrorist activity at the chosen destination). The chain of events which could take place between the time of booking a vacation and the behavioral outcome of the decision process can extend IIT beyond the point of final choice. If potential tourists obtain new and negative information about a destination (after it has been chosen), it is likely for these individuals to integrate that knowledge into the decision process, even if it means altering the outcome by canceling plans.

Supported by theories of risky decision-making and the accepted models of consumer and tourist decisionmaking, this study suggests that decisions are influenced by several factors as they progress through a sequence of stages. Subject to sociodemographic and psychographic influences, motivation to travel results from various personal, social, or commercial cues.

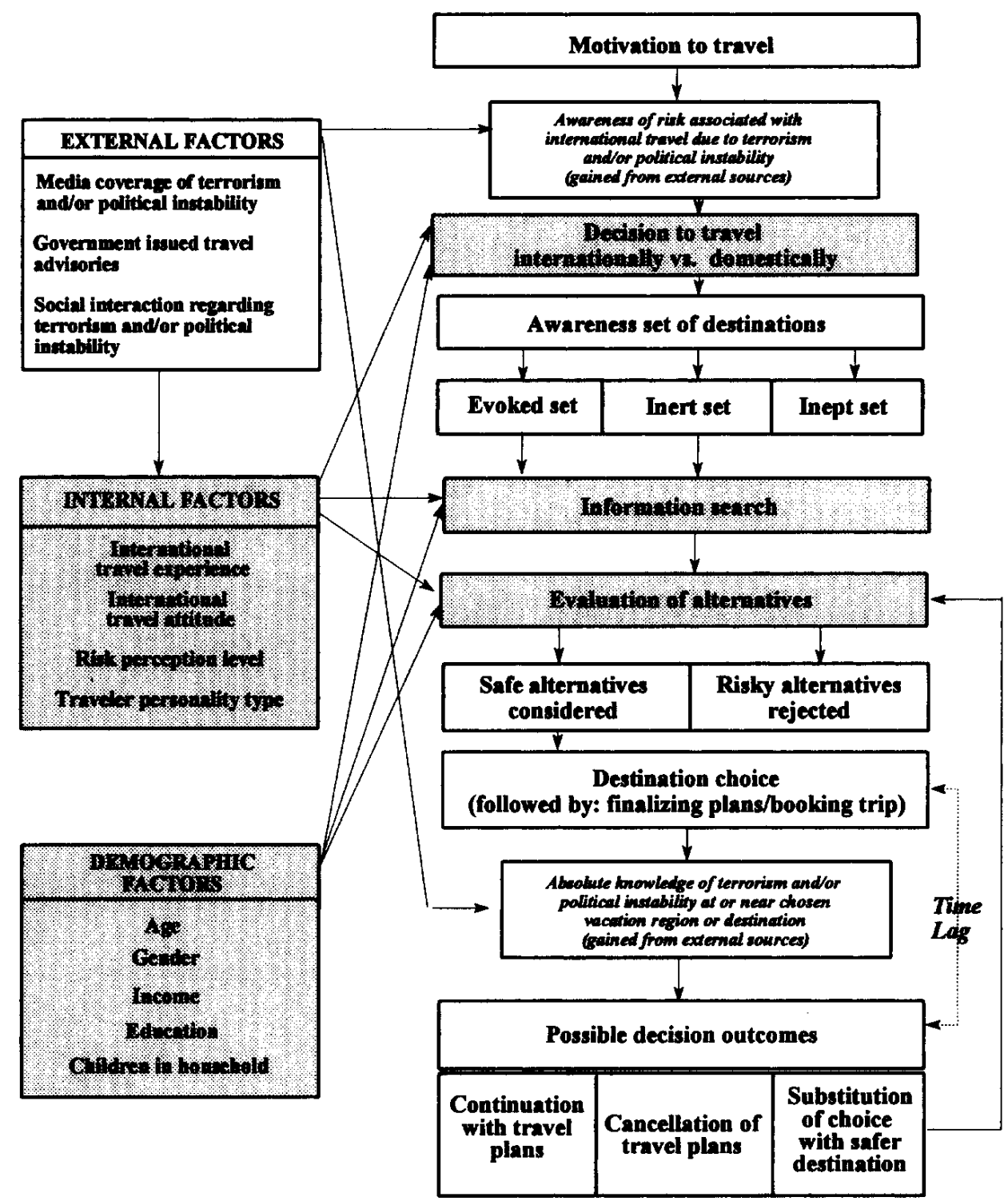

Figure 1. Model of International Tourism Decision-Making Process. Adapted from Engel, Kollat and Blackwell (1968); Howard (1963, 1977); Mansfeld (1992); Um and Crompton (1990); vanRaaij and Francken (1984) 
An awareness of terrorism or political turmoil risk associated with international tourism may already exist due to personal experience. This awareness, which may also develop as a result of exposure to external factors, such as media coverage, travel advisories, or social interaction, is a potential influence on the rest of the decisionmaking process. In the next stage, individuals decide whether or not to travel to a foreign country as opposed to a domestic destination. The propensity for the international choice may depend on several internal or demographic factors (Figure I).

The awareness set of destinations includes those individuals have learned about incidentally or through passive or informal information search. These alternatives are often influenced by personal attitudes toward various regions or destinations. Destination alternatives are grouped further into sets based on their desirability. The evoked set contains destinations about which active or formal information search will take place. The inert set includes those about which the individual is either undecided or insufficiently informed. Destinations in the inept set are rejected due to negative perceptions or perceived risks. In the next stage, active or formal information search is conducted on those in the evoked and possibly inert sets. Travel professionals, literature, and advisories, as well as various other sources, might be consulted at this stage. The extent of information search is likely to depend on previous experience, risk perceptions, or the importance of the vacation. The amount of information needed may also depend on demographic factors as well as other internal factors. Thus, destinations are evaluated according to their safety and risk factors with regard to terrorism and political problems. Different levels of concern for safety may influence the evaluation process. Destinations perceived as safe from terrorism and political problems will be considered seriously, while those perceived as risky will be rejected. A destination choice is made by selecting the most desirable alternative from among those considered safe. Potential tourists select the destination which best matches their needs by offering the most benefits for the least cost (or risk).

It is possible for potential tourists to acquire definite information about terrorism or political problems at or near the chosen destination, after booking a vacation. This knowledge could result from media coverage, travel advisories, or social interaction, following the final destination choice. Such information has the potential to impact the outcome of the decision which, depicted in the last stage, refers to the behavioral component of the decision-making process. The outcome can confirm or reject previous decision-making stages. Continuation with plans involves carrying out the decision without being influenced by external factors, in which case traveling as planned may lead to satisfaction or dissatisfaction. Either one will provide internal information and experience for future decisions. Cancellations due to impacts of internal (e.g., risk perception) or external (e.g., media coverage of terrorism) factors entail staying home. Substitution of the destination choice, with another perceived as safer, involves returning to the decision process to select another international or domestic destination. It is difficult to predict the time frame within which a vacation is actually booked and the outcome of the decision is revealed. World events are unpredictable as are individuals' wishes to carry out or change travel plans. The process of destination choice can begin again when individuals return to earlier stages, such as the evaluation of alternatives or reviewing the set of destinations considered to be safe from threat.

Several internal factors have potential influence on each of the key stages of the travel decisions. As already noted, past international experience may provide confidence for future travel, despite individuals' awareness of terrorism threat. Conversely, negative experiences may make potential tourists nervous about future options. It is fair to assume that those who associate high risk with international travel will prefer vacationing at homepresuming that domestic destinations are perceived as safe. The level of perceived risk may also dictate the amount of information search, which has been identified as a risk reduction strategy undertaken by the potential tourist (Roehl and Fesenmaier 1992). Individuals may exhibit information needs which parallel their risk perceptions. Attitudes can impact their decisions and behavior. Potential tourists may feel most comfortable with a domestic vacation due to negative attitudes toward international options. Similarly, an individual with positive attitudes toward international travel in general may not exhibit high levels of concern for safety when evaluating destinations. 
Personality characteristics of potential tourists may also be central to their vacation choice and planning. According to Plog (1974:55-56), allocentric individuals are self-confident, adventuresome, and prefer novel experiences; whereas, psychocentrics are conservative, seek safety, and prefer the familiar. Within the limits of Plog's tourist personality continuum (moving from psychocentrism to allocentrism), one could assume psychocentrics require a lot of information, are less inclined to go abroad, and very concerned about destination safety, with allocentrics demonstrating opposite tendencies. In addition to psychographic characteristics, tourists' sociodemographic profiles may have important impacts on their destination choices. For example, concern for safety may decline with higher levels of education, increase with age and reach an all time high for those with small children in their households. This may further be influenced by income level and gender. For example, Arch (1993) found that even when conditions are the same for both males and females, gender makes a difference. For instance, females were found to be less interested in risk-taking activities than males, especially those with care-taking responsibilities.

Based on this proposed model, with a special emphasis on propensity for international tourism, degree of information search, and the level of concern for safety in evaluating destination alternatives (Crompton 1992; Mansfeld 1992; Mazursky 1989; vanRaaij and Francken 1984), three sets of hypotheses may be framed with the direction of suggested relationships indicated in parentheses. Given an awareness of terrorism and/or political instability risk:

H1: The propensity for international tourism is directly associated with international experience (positively), risk perception level (inversely), international attitude (positively), personality type (positively), age (inversely), gender (positive association between males and propensity for international), education (positively), income (positively), and presence of children in the household (inversely).

H2: The extent of information search conducted during decision-making is directly associated with international experience (inversely), risk perception level (positively), international attitude (positively), personality type (positively), age (positively), gender (positive association between females and information search), education (positively), income (positively), and presence of children in the household (positively).

H3: The degree of concern for safety in evaluating destination alternatives is directly associated with international experience (inversely), risk perception level (positively), international attitude (inversely), personality type (inversely), age (positively), gender (positive association between females and concern for safety), education (inversely), income (inversely), and presence of children in the household (positively).

\section{Study Methods and Variables}

A sampling frame of individuals, who either traveled internationally in the past or expressed an interest in doing so, was obtained from a mail list broker (Dunhill International List Co., Inc.). This included individuals who responded to tourism related surveys and who contacted travel agencies for information. Because the study's focus was international, it was considered both necessary and appropriate to sample individuals whose interests paralleled the research topic (rather than the general population). From a national random probability sample of approximately 1,100 names (drawn in proportion to populations of all 50 states of the US, Puerto Rico, and the US Virgin Islands), a systematic random sampling was conducted ( $\mathrm{N}=1,100$; interval=2). A final sample of 500 was determined necessary in order to carry out planned statistical procedures. Data were collected through a mail survey. Initially, a partial three-step implementation of the multiple mailing process (Dillman 1978), was utilized. Two complete questionnaires and a postcard reminder were mailed during the spring of 1994. To increase response rate, brief telephone calls were placed to non-respondents. A $48 \%$ response rate was achieved with 240 usable surveys. To address the question of possible non-response bias, a systematic random sample of non-respondents $(\mathrm{N}=30)$ was selected and interviewed by telephone. Differences between respondents and nonrespondents were tested and frequency distributions of the telephone survey data were analyzed.

Results of the phone survey revealed that non-respondents had less international experience than those who responded to the mail survey $(t=3.45 ; p=.001)$. Significant differences were found in the extent of information 
search between the two groups $(\mathrm{t}=4.90 ; \mathrm{p}=.000)$. Non-respondents reported less information search than respondents and were also less concerned with safety than their counterparts $(t=2.27 ; p=.024)$. Compared with respondents, non-respondents were more likely to be females $\left(\chi^{2}=6.89 ; \mathrm{df}=1 ; \mathrm{p}=.009\right)$ with lower levels of education $\left(\chi^{2}=19.18 ; \mathrm{df}=5 ; \mathrm{p}=.002\right)$.

The survey instrument was a self-administered, five part questionnaire. Questions in the first part of the survey asked about respondents' past international experience, intentions for future trips, attitudes toward international tourism, and personality type. The second and third sections focused on their risk perceptions and inter-national decisions. More specifically, their propensity for international trips and their concerns for safety in destination evaluation were gauged. The fourth section posed questions regarding their sources of information and the extent of their search and the final section obtained sociodemographic data.

For this survey international experience was defined as the extent of travel to a destination outside the boundaries of subject's country of residence. Both consumer and tourism decision-making literature suggest that personal experience is integrated into decision-making as passive or internal information search (Crompton 1992; Evans and Berman 1992; Howard 1963; Um and Crompton 1990). Mazursky (1989) suggests that future behavior may be influenced by the nature as well as extent of past experience. Only the extent of the latter was measured in this study. Three single-item screening questions ("do you travel internationally for business?" " ... for vacations?" "what year did you last travel internationally?") established past experience.

The extent of experience was measured by two multiple-item questions, regarding the number of international trips undertaken in the past five years and the number of international trips in one's lifetime. Using a multipleitem question, the range of international experience was measured by the number of different regions the individual visited in the past. Answers, which resulted in three subscales, were standardized and then added to create an overall "international travel experience scale".

Risk perception level was defined as the amount and types of risk potential tourists associate with international tourism. The literature suggests that perceived risk influences the evaluation of destination alternatives and information acquisition (Roehl and Fesenmaier 1992; Weber and Bottom 1987). Risk perception was measured with four subscales. First, subjects were asked about their perceptions of safety/ risk with regard to 50 countries listed in alphabetical order, on a six-point Likert-type scale ("very safe" to "very risky" and "don't know"). Second, subjects were presented with ten types of risk and asked which (and how much) they associate with international tourism on a six-point Likert-type scale ("none" to "very high"). Seven of the risks (financial, functional/equipment, physical, psychological, social, satisfaction, time) have been used previously in leisure and tourism research (Cheron and Ritchie 1982; Roehl and Fesenmaier 1992) as well as consumer behavior studies (Schiffman and Kanuk 1991). Health, political instability, and terrorism risks were added to remain within the framework of the study. Third, subjects were asked about their level of agreement with 15 statements regarding risks associated with international travel (such as "international travel is risky," "politically unstable countries should be avoided by tourists", "I feel nervous about traveling internationally"), on a five-point Likerttype scale ("strongly agree" to "strongly disagree"). Further, subjects' responses to five safety/risk-related adjectives within a longer, 19-item seven-point semantic differential scale used to determine international tourism attitude (i.e., "international travel is ... secure/ risky, threatening/non-threatening, comforting/terrifying, scary/ reassuring, safe/dangerous") were used as a subscale of risk perception. Answers to the four subscales were standardized and combined into a "risk index".

International attitude reflects individuals' beliefs, feelings, and behavioral orientations with respect to international tourism. Attitude has been identified as a critical factor in tourism-related decisions (Goodrich 1978; Um and Crompton 1992). The cognitive component of attitude was measured by asking subjects to rate, 19 bipolar descriptors on a seven-point semantic differential scale (such as "inter-national tourism is ... negative/positive, relaxing/stressful, meaningful/ meaningless, valuable/worthless"). The affective component of attitude was measured by subjects' level of agreement with eight statements (such as "international tourism is enjoyable", "I don't like vacationing in foreign countries", "international tourism is a positive experience") on a 
five-point Likert-type scale ("strongly agree" to "strongly disagree"). To avoid a response tendency, negative and positive poles of the scale were alternated (Osgood, Suci and Tannenbaum 1957). Answers to the affective and cognitive subscales were standardized and combined to create an overall scale of attitude toward travel to international destinations.

Tourist personality type represents the psychological makeup of the respondent according to Plog's continuum (Plog 1974, 1990), ranging from psychocentric/stabilizer to allocentric/venturesome. With special permission, personality type was measured using four questions on a four-point Likert-type scale ("very much", "somewhat", "a little", "not at all") developed and revised by Plog (1974, 1990). The four items factored together in an earlier analysis conducted by Plog which involved 20 personality/lifestyle related items. Answers to the four questions resulted in a measure of the respondents' personality type. Demographic variables of age and income were interval level variables, education was ordinal data. Gender $(0=$ male; $1=$ female $)$ and presence of children in the household $(0=$ no children at home; $1=$ children at home $)$ were used as dichotomous variables.

Propensity for international tourism versus domestic was defined as individuals' propensity for international vacation travel. This inclination was measured by the individual's level of agreement with nine statements (such as "terrorism has never influenced my decision to travel internationally") presented on a five-point Likert-type scale ("strongly agree" to "strongly disagree"). On an interval scale, this variable ranged from no propensity to high propensity for international tourism.

Information search was defined as the extent of active or formal search for data about alternatives prior to their evaluation. The extent of information search conducted by subjects was measured by a scale including 12 information sources (such as "friends and family members, travel professionals, government travel advisories and foreign embassies/consulates, word-of-mouth information, travel magazines"). The question, regarding their use, was posed on a five-point Likert-type scale ("always use" to "never use"). The variable ranged from no to extensive information search. Finally, evaluation of alternatives was defined as the use of safety as the determining attribute to classify foreign destinations into groups of considered and rejected alternatives, as well as the general concern for safety in the evaluation process. Subjects' concern with safety in evaluating destination alternatives was measured by nine statements (such as "safety is the most important attribute a foreign country can offer") presented on a five-point Likert-type scale ("strongly agree" to "strongly disagree"). The scale comprised by the nine items ranged in value from no concern to extreme concern for safety.

\begin{tabular}{lccc} 
Table 3. Cronbach's alpha Coefficient Scores of Subscales and & \multicolumn{3}{c}{ Overall Scales } \\
\hline Scales & Alpha & N & Items \\
\hline Independent Variables & & & \\
International Tourism Experience Scale & & & \\
$\quad$ Subscale 1: International Travel Experience & 0.79 & 239 & 3 \\
$\quad$ (past 5 years) & 0.76 & 240 & 4 \\
$\quad$ Subscale 2: Range of International Travel Experience & 0.62 & 240 & 12 \\
$\quad$ Subscale 3: International Travel Over Lifetime & 0.62 & 239 & 12 \\
Risk Perception Level (Risk Index) & 0.74 & 205 & 4 \\
$\quad$ Subscale 1: Risk Perceived in 50 Countries & 0.95 & 224 & 50 \\
$\quad$ Subscale 2: Risk Types Perceived in International & 0.86 & 228 & 10 \\
$\quad$ Travel & & & \\
$\quad$ Subscale 3: Risk Associated With International Travel & 0.89 & 225 & 15 \\
$\quad$ Subscale 4: Travel Attitudes Involving Risk & 0.88 & 239 & 5 \\
International Travel Attitude Scale & 0.87 & 213 & 2 \\
$\quad$ Subscale 1: Cognitive Component Scale & 0.65 & 230 & 19 \\
$\quad$ Subscale 2: Affective Component Scale & 0.93 & 220 & 8 \\
Traveler Personality Type & 0.36 & 232 & 4 \\
$\quad$ (Psychocentrism-Allocentrism scale) & & & \\
Dependent Variables = & & & \\
$\quad$ Decision to Travel Internationally versus Domestically & 0.88 & 228 & 9 \\
$\quad$ Extent of Information Search & 0.82 & 233 & 12 \\
$\quad$ Concern for Safety in Evaluation of Destination & 0.83 & 229 & 9 \\
$\quad$ Alternatives & & & \\
\hline$\quad$ & & &
\end{tabular}


Reliability of scales developed to measure both independent and dependent variables was tested by using Cronbach's alpha coefficient. The attitude scale was found to be the most reliable (alpha $=.87$ ), followed by tourism experience $($ alpha $=.79)$ and risk index $($ alpha $=.74)$, as shown in Table 3. Personality type emerged as the least reliable scale $($ alpha $=.36)$ and was eliminated from the analysis.

Multiple regression analysis was used to test hypothesized relationships and to identify independent variables exerting the strongest influence in key decision steps. Gender and presence of children in the household were treated as dummy variables. All other variables were examined at the interval level (education, while strictly speaking an ordinal variable, was treated as interval in the regression analysis). Additional analyses of relationships between independent variables were conducted. First, risk perception and attitude were each treated as the dependent variable and tested against experience in two simple regression analyses. Next, multiple regression analyses were used to examine relationships between each of the five demographic variables (independent variables) and experience, risk perception and attitude (treated as dependent variables). Two sample t-tests were used to determine differences between respondents and non-respondents in the analysis of non-response bias.

\section{Study Results}

Respondents were primarily older, well educated and affluent males (70\%). Well over half (65\%) of the sample was 46 or older; the average age was 51 . More than $70 \%$ of the respondents reported having a college or graduate degree. An annual household income of $\$ 50,000$ or more was reported by the majority $(70 \%)$ of respondents; nearly $20 \%$ reported incomes of $\$ 100,000$ or more. Most of the respondents were found to be in the "empty nest" stage of the family life cycle. Only $24 \%$ of the sample had children under 18 living at home. Respondents reported the United States as their predominant country of birth (92\%), citizenship (98\%), and residence $(98 \%)$.

Respondents emerged as seasoned tourists with relatively current experience. About $95 \%$ traveled internationally (for business or pleasure) some time in their lives. About 60\% of them traveled between 1990 and 1993, and 20\% traveled in 1994. Respondents also demonstrated breadth in their experiences. For example, over 35\% reported travel to between one and three international regions (e.g., Central America, Middle East, Asia, and Europe), $40 \%$ to between four and six regions, and $20 \%$ to seven or more regions. Nearly $76 \%$ expressed intent to travel internationally in the coming year. As to their attitude, results revealed a generally positive desire toward international tourism. For example, $88 \%$ of respondents agreed that "international tourism is enjoyable" and that "international tourism is a positive experience". In addition, vacation away from home was considered more "positive" than "negative", more "interesting" than "boring", and more "pleasurable" than "unpleasurable".

Although high levels of perceived risk associated with international tourism in general were not found, respondents expressed concern regarding terrorism or political turmoil. For example, nearly $67 \%$ of respondents agreed they were "very comfortable traveling inter-nationally". Yet 54\% noted feeling safer "when traveling domestically". Nevertheless, $88 \%$ of respondents agreed that "politically unstable countries should be avoided by tourists". Out of the 50 countries listed, Canada, New Zealand, Switzerland, Sweden, and Australia were identified as the five safest. The United States emerged as the ninth safest country. It is possible that this was reported as a safe country because respondents were predominantly American. Countries perceived to be the riskiest included Iraq, Somalia, Libya, Lebanon, and Syria. This finding might be linked to political tension between each of these countries and the United States. Respondents most often associated health, financial, political instability, equipment, and terrorism risks with international travel. Further results imply that respondents' propensity for international tourism may be somewhat constrained by concerns about terrorism or political instability. For example, $57 \%$ agreed that "the possibility of terrorism discourages" them from international tourism.

Study results demonstrated that social sources of information were preferred to more formal sources, during information search. Respondents reported using personal experiences (84\%) and travel professionals (57\%) 
most often. Over half $(57 \%)$ of the respondents indicated they consider other people's experiences. In addition, $53 \%$ of respondents revealed they consult family or friends, $47 \%$ seek out business associates and peers for advice, and about $50 \%$ listen to word-of-mouth information. Less popular sources of information included embassies and consulates of foreign countries; seldom used by $70 \%$. Over $40 \%$ of respondents said they seldom use government issued travel advisories. Safety emerged as an important consideration during the evaluation process. About $77 \%$ of respondents said they would travel only to countries they "believe are safe". Nearly $79 \%$ of respondents disagreed that "terrorism risk is not a factor" when evaluating foreign countries.

The original eight independent variables (age, gender, education, income, children in household, experience, attitude, risk perception) in the regression model explained about $49 \%$ of the variance in the decision to travel internationally versus domestically. Only attitude and risk perception level emerged as significant predictors. In the second analysis, which was run with only those two variables, $48 \%$ of the variance was explained (Table 4). Propensity for international tourism was found to be determined by more positive attitudes and lower levels of perceived risk. In general, only those two hypothesized relationships (H1) were supported by the results. About $24 \%$ of the variance in the extent of information search was explained by the eight independent variables in the first analysis. In order of strength, attitude, income level, and risk perception level were the most significant predictors of information search. Twenty-one percent of the variance was explained, in the second analysis, with only those three independent variables (Table 4). Respondents' extent of information collection increased as their attitudes improved and their perceived risk and income levels increased. The results partly supported the hypothesized relationships $(\mathrm{H} 2)$.

Over $24 \%$ of the variance in the concern for safety in the destination evaluation was explained by the eight independent variables (Table 4). Risk perception level followed by attitude were the strongest predictors of safety concerns. As the only two variables in the second analysis, risk perception and attitude explained about $24 \%$ of the variance. Results imply that concern for safety increases with risk perception levels but decreases with more positive attitudes. Results partly supported the hypothesized relationships (H3). Overall, results indicate that potential travelers' risk perceptions, attitudes, and income levels are significant predictors of key decision-making stages. Interestingly, neither international experience nor other demographic factors were found to predict any key decision components directly. To better understand the role of those variables, further tests were run.

Table 4. Multiple Regression of Internal Factors

\begin{tabular}{|c|c|c|c|}
\hline \multirow{2}{*}{$\begin{array}{l}\text { Demographic/ } \\
\text { internal factors }\end{array}$} & $\begin{array}{l}\text { Decision to Travel } \\
\text { Internationally }\end{array}$ & $\begin{array}{l}\text { Extent of } \\
\text { Information } \\
\text { Search }\end{array}$ & $\begin{array}{l}\text { Concern for } \\
\text { Safety } \\
\text { Evaluation of } \\
\text { Alternatives }\end{array}$ \\
\hline & r Beta b & r Beta b & r Beta b \\
\hline Age & -.003 & .061 & -.043 \\
\hline Gender & .008 & .058 & .085 \\
\hline Education & $.218^{\mathrm{b}}$ & $.184^{\mathrm{b}}$ & $-.191^{b}$ \\
\hline Income & .073 & $.217^{\mathrm{b}} .150^{\mathrm{b}} 2.561$ & -.056 \\
\hline Children in Household & $-.147^{\mathrm{a}}$ & .003 & .062 \\
\hline International Experience & .312 & .089 & $-.256^{c}$ \\
\hline Risk Perception Level & $-.463^{c}-.354^{c}-2.408$ & $.095 .170^{\mathrm{b}} 1.315$ & $.381^{\mathrm{c}} .313^{\mathrm{c}} 1.552$ \\
\hline \multirow[t]{4}{*}{ International Attitude } & $.600^{\mathrm{c}} .527^{\mathrm{c}} 3.685$ & $.403^{b} .410^{c} 3.462$ & $-.378^{c}-.310^{c}-1.590$ \\
\hline & $N=178$ & $N=179$ & $N=183$ \\
\hline & $\mathrm{R}^{2}=.481^{\mathrm{c}}$ & $\mathbf{R}^{2}=.214^{\mathrm{c}}$ & $\mathrm{R}^{2}=.236^{\mathrm{c}}$ \\
\hline & Constant $=27.94$ & Constant $=31.41$ & Constant $=33.495$ \\
\hline
\end{tabular}

${ }^{\mathrm{a}} .05,{ }^{\mathrm{b}} .01,{ }^{\mathrm{c}} .001$

Two simple regression analyses were conducted in which international experience remained as an independent variable, but risk perception level and international attitude were treated as dependent variables. Experience was found to be significantly related to both dependent variables (Table 5). As respondents' experience increased, their risk perception levels decreased and their attitudes toward international tourism improved. Results suggest that experience may be indirectly related to the three key stages of decision-making through its influence on these factors. Three additional sets of multiple regression analyses were run, in which demographic variables 
remained independent variables and experience, risk perception, and attitude were treated as dependent variables. For experience, all five demographic variables emerged as significant predictors at the bivariate level, but income and education were the only two significant predictors in the regression model. The analysis was rerun with only those two variables and explained about $13 \%$ of the variance (Table 6). Not surprisingly, as respondents' education and income levels increased, so did their international experience.

Table 5. Simple Regression of International Experience

\begin{tabular}{|c|c|c|}
\hline Internal factor & $\begin{array}{l}\text { Risk perception } \\
\text { r Beta }^{\mathrm{d}}\end{array}$ & $\begin{array}{l}\text { Attitude } \\
\text { r Beta }^{\mathrm{d}}\end{array}$ \\
\hline Travel Experience & $\begin{array}{c}-.152^{\mathrm{b}}-.152^{\mathrm{a}} \\
\mathrm{R}^{2}=.023^{\mathrm{a}} \\
N=204\end{array}$ & $\begin{array}{c}.352^{\mathrm{c}} .352^{\mathrm{c}} \\
\mathrm{R}^{2=} .124^{\mathrm{c}} \\
N=212\end{array}$ \\
\hline
\end{tabular}

${ }^{\mathrm{a}} .05,{ }^{\mathrm{b}} .01,{ }^{\mathrm{c}} .001,{ }^{\mathrm{d}}$ Space restrictions of this table only permitted display of Standardized Beta Coefficients

Table 6. Multiple Regression of Demographic Factors

\begin{tabular}{lcc}
\hline Demographic factors & $\begin{array}{c}\text { International experience } \\
\text { r Beta b }\end{array}$ & $\begin{array}{c}\text { International attitude } \\
\text { r Beta b }\end{array}$ \\
\hline Age & $.285^{\mathrm{c}}$ & .017 \\
Gender & $-.195^{\mathrm{b}}$ & -.004 \\
Education & $.232^{\mathrm{c}} .284^{\mathrm{c}} .601$ & $.346^{\mathrm{c}} .346^{\mathrm{c}} 1.074$ \\
Income & $.312^{\mathrm{c}} .191^{\mathrm{c}} .604$ & $.136^{\mathrm{a}}$ \\
Children in Household & $-.121^{\mathrm{a}}$ & $-.129^{\mathrm{a}}$ \\
& $N=228$ & $N=212$ \\
& $\mathrm{R}^{2}=.133^{\mathrm{c}}$ & Constant $=-.975$ \\
$\mathrm{R}^{2}=.120^{\mathrm{c}}$ & Constant $=-.947$ \\
\hline
\end{tabular}

${ }^{\mathrm{a}} .05,{ }^{\mathrm{b}} .01,{ }^{\mathrm{c}} .001$

In the analysis involving attitude and demographic variables, age, education, and income showed significant bivariate correlations with the dependent variable. Only education emerged as a significant predictorexplaining $12 \%$ of the variance in attitude (Table 6). Higher education indicated more positive touristic attitudes. Surprisingly, none of the demographic variables was a significant predictor of risk perception level. Sociodemographic variables were clearly unable to explain why some respondents perceived higher levels of risk than others in the study sample. A broad look at the results of all statistical analyses shows that attitude, risk perception level, and income are directly related to key stages of decision-making. They also mediate the influences of experience, education, and income, which indirectly affect key decision stages. The model of touristic decisions involving terrorism risk (Figure 1) was revised to illustrate results of the hypothesis tests. Figure 2 summarizes the significant direct and indirect relationships between variables in this study.

Attitude toward international tourism, risk perception level, and income emerged from the analysis as the strongest predictors of decisions involving terrorism risk/political instability. According to study results, these factors determine if potential tourists will go abroad or vacation at home, how much information they will gather about the destination, and how concerned they will be about its safety in light of terrorism threat. Findings support earlier studies, in which attitudes (Goodrich, 1978; Um and Crompton, 1992) and information gathering were found to be critical in tourism related decisions. Results imply that people who associate various risks with inter-national tourism (e.g., health and terrorism) are less inclined to leave home (for such people, vacationing in the United States may be more appealing than going to Europe or Asia). Propensity for international tourism was also determined by attitude; those with more positive attitudes were found to be more inclined to choose international vacation destinations. 
Information search was identified as a common risk reduction strategy by Roehl and Fesenmaier (1992). Results of this study support their finding. Attitude, risk perception level, and income were found to predict the amount of information someone would gather during touristic decisions involving terrorism risk. The attitude component of this finding may be linked to Buchanan's (1985) finding that commitment to a leisure activity involves a higher level of investment, if information search is viewed as an investment of time and effort. Those with a positive tourism attitude are likely to spend time examining travel-related magazines and videos, consulting travel professionals, reading guidebooks and studying brochures.

Results also support prospect theory's (Kahneman and Tversky 1979) proposition that risky choices indicate risk seeking behavior, whereas safe choices indicate a risk averse personality. Attitude toward overseas tourism was also found to predict safety concerns. More positive attitudes implied less concern for safety despite terrorism risk (perhaps this could be explained by the power of optimism). This finding parallels prospect theory's (Kahneman and Tversky 1979) proposition that risk perceptions influence the attractiveness of choices and their evaluation. Indeed, study results found that concern about destination safety increased with risk perception level. It is not surprising that those who believe international tourism poses terrorism risks were more concerned about the safety of a particular region or destination. For these individuals, safety could very well become the deciding factor when choosing a vacation spot. This idea also ties into information integration theory (Anderson 1981, 1982) — to choose a safe destination, potential tourists may rank alternatives according to subjective perceptions of terrorism threat. Negative information acquired after a destination has been selected can have the potential to change the decision outcome (i.e., cancellation and substitution).

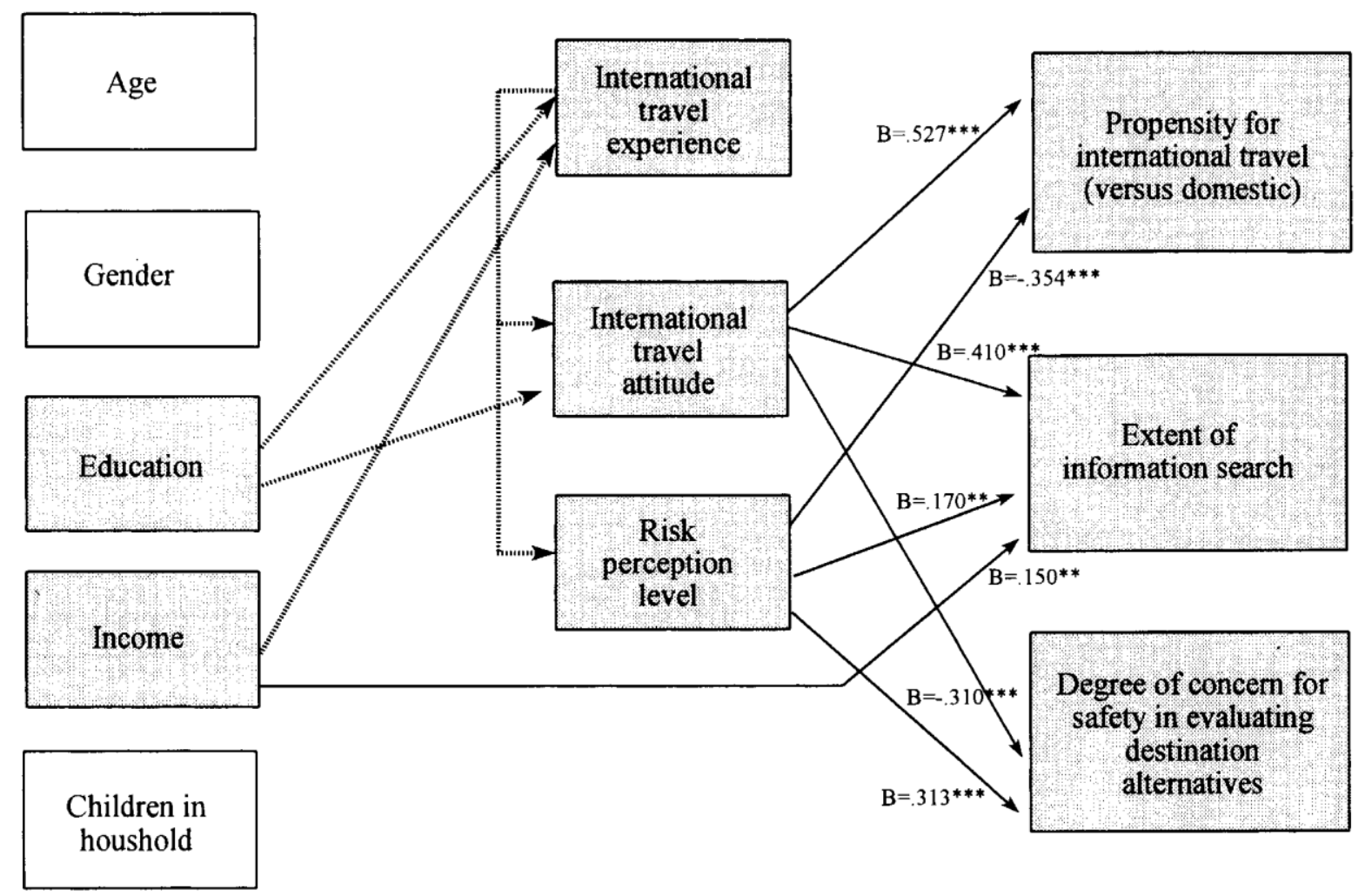

Figure 2. Revised Model of Internatioanl Tourism Decision-Making (representing results of multiple regression analyses used to test hypotheses with solid lines to indicate direct relationships and broken lines to indicate indirect relationships). Significance levels: $* .05, * * .01, * * * .001$

Surprisingly, neither demographic characteristics nor past experience were directly related to any of the key decision stages. At the outset of this study, past experience, in particular, was expected to influence future decisions, by serving as a frame of reference. It is likely that decisions involving terrorism risk are influenced more by the quality and less by the extent of past international experience. Experiencing or witnessing a terrorist attack just once, for example, is likely to color future behavior, regardless of the extent of past 
experience. Results of simple regression analyses did infer that risk perception levels diminish as experience increases. But, an experience that puts the individual in serious danger could very well heighten perceptions of risk.

\section{CONCLUSION}

The study has several limitations that should be recognized when interpreting the results. First, findings might not be generalizable to the general population since only individuals who have traveled internationally or have demonstrated an interest to visit international destinations were sampled. Second, findings might be limited by the nature of the sampling frame. A list of names, comprising individuals who previously responded to tourismrelated surveys or who contacted travel professionals for information, was obtained from a mail list broker. Because it is virtually impossible to determine all circumstances relevant to the compilation of the mail list, inferring study findings to the general public is not recommended. Third, study findings might not be generalizable to non-US populations, since the investigation was conducted in the United States. Subjects' responses could be influenced by their cultural backgrounds as well as their social/cultural environment. Such responses might be different according to the environment in which the investigation is conducted. Cultural differences in risk perception magnitude and source of perceived hazards have been found in cross cultural studies of perceived risk (Goszczynska, Tyszka and Slovic 1991; Mechitov and Rebrik 1990; Tiegen, Brun and Slovic 1988). Fourth, subjects' perceptions of terrorist threat might be heightened by print and broadcast media coverage of current terrorist events and/or political instability or, to the contrary, such perceptions might be diminished by the lack of current terrorism and/or political instability. Thus, the absence of relevant publicized events during the study's investigative process might have influenced responses to the research questionnaire. Moreover, internal factors measured in this study might not fully represent all of the influences on international vacation decisions and their outcomes. For example, intensive marketing activities by a particular destination could overcome perceived threats of terrorism.

Several other dimensions of this topic need further investigation. For example, impacts of situational factors (refer to Figure 1) on touristic decisions need to be examined. Can watching a terrorist incident on the evening news or conversing with someone who has experienced a military coup actually influence vacation decisions? Second, the links between real and perceived risk and their influences on decisions, need illumination. Watching violent images of terrorism or regional war on television is probably enough to discourage most people from traveling. Media sensationalism can cloud actual probabilities of being the victim of terrorist attack. Perceived risk may overcome reality when personal safety is involved. It is crucial for destination marketers to understand touristic perceptions in order to tailor promotional messages accordingly.

Communications need to address tourist concerns, alter false negative perceptions, and reinforce positive ones. Potential tourists deserve correct information about risks and dangers. At the same time, unfounded perceptions of risk can seriously hurt a destination. Finally, a more reliable measure of tourist personality type than what is presently available needs to be developed. As a method of analyzing consumer behavior, the "diffusion process" is used to predict how a target market will accept and purchase new products or services (Lai 1991; LaTour and Roberts 1992; Midgley and Dowling 1993; Pennings and Harianto 1992). Innovators are the first to try new products and services. They are followed by early adopters, the early majority and then the late majority. Laggards comprise the last group to adopt new products and services. Each of these categories is identified by sociodemographic and psychographic characteristics. The possibility of identifying tourist personalities, according to individuals' willingness to try new or unusual destinations or experiences, needs to be investigated. It might be possible to integrate the personality continuum developed by Plog (1974) with the diffusion process, in order to achieve a reliable measure of tourist personality.

In summary, this study has attempted to examine international touristic decisions made within the context of terrorism risk. Decisions involving risk in general or terrorism risk in particular, involve a complicated process that has received little research attention. Whether real or perceived, risks associated with international tourism place serious constraints on tourist behavior. While tourism motivations have been studied at length, far less notice has been paid to constraints on touristic behavior. Unlike business travelers, those on vacation enjoy the element of choice; tourists are free to choose which country to visit and which to avoid. Therefore, it is not 
surprising for those going on vacation to be easily deterred by threats of terrorist attack or risks of becoming embroiled in another country's political conflict. Even a cursory look at tourism figures, following terrorism in 1985 or the 1991 Persian Gulf War, leaves little doubt about the power of terrorism and political conflict to constrain touristic behavior. It is likely that behavior is as constrained by perceived risk as it is by actual risk.

Study results have demonstrated that, besides risk, factors which directly influence risky international decisions include attitude toward foreign travel, risk perception level, and income. It may benefit travel professionals to better understand these influences, in order to plan and implement marketing activities to counteract them. Additionally, increasing sensitivity to customer characteristics is more likely to help marketers predict choice and purchase behaviors. In turn, appropriate regions and destinations, modes of travel, and other trip characteristics can be more easily determined and successfully marketed. The tourism industry's vulnerability to terrorism is proportionate to its reliance on peace and stability. Even with an optimistic view of global complexities, it is difficult to imagine a future world without terrorism. While governments search for methods to minimize threats posed by terrorism, it would benefit the international tourism industry to examine market variables (e.g., consumer behavior and decision-making), as a way of mitigating negative impacts of terrorism and political turmoil on tourism.

\section{REFERENCES}

Abu Fadil, M.

1992 Special Feature: The Terrorists Won't Go Away. The Middle East 217:15-18. Alexander, Y. 1977 Communications Aspects of International Terrorism. International Problems 16:55-60.

Allan, R.

1990 Terrorism: Pragmatic International Deterrence and Cooperation, Occasional Paper Series, 19. New York: Institute for East—West Security Studies. Anderson, N. H.

1981 Foundations of Information Integration Theory. New York: Academic Press. 1982 Methods of Information Integration Theory. New York: Academic Press. Arch, E. C.

1993 Risk-taking: A Motivational Basis For Sex Differences. Psychological Reports 73(1):3-11.

Arendt, $\mathrm{H}$.

1971 The Origins of Totalitarianism. New York: Harcourt Brace Jovanovich. Aziz, H.

1995 Understanding Attacks on Tourists in Egypt. Tourism Management 16:91— 95.

Bar-On, R. R.

1996 Measuring the Effects on Tourism of Violence and of Promotion Following Violent Acts In Tourism, Crime and International Security Issues, A. Pizam and Y. Mansfeld, eds., pp. 159-174. New York: Wiley.

Bell, J. B.

1975 Transnational Terror. Washington DC: American Enterprise Institute.

1978 A Time of Terror: How Democratic Societies Respond to Revolutionary Violence. New York: Basic Books.

Bolz, Jr., F., K. J. Dudonis and D. P. Schulz

1990 The Counter-Terrorism Handbook. New York: Elsevier Co., Inc. Brady, J. and R. Widdows

1988 The Impact of World Events on Travel to Europe During the Summer of 1986. Journal of Travel Research 26(3):8-10.

Buchanan, T.

1985 Commitment and Leisure Behavior: A Theoretical Perspective. Leisure Sciences 7:401-420.

Buckley, P. J. and M. Klemm

1993 The Decline of Tourism in Northern Ireland: The Causes. Tourism Management 14:184-194.

Cheron, E. J. and J. R. B. Ritchie

1982 Leisure Activities and Perceived Risk. Journal of Leisure Research 14:139- 154.

Conant, J. S., T. Clark, J. J. Burnett and G. Zank

1988 Terrorism and Travel: Managing the Unmanageable. Journal of Travel Research 26(4):16-20.

Cook, R. L. and K. W. McCleary

1983 Redefining Vacation Distances in Consumer Minds. Journal of Travel Research 22(2):31-34.

Crenshaw, M. 
1989 Terrorism and International Cooperation. Occasional paper series 11. New York: Institute for East-West Security Studies.

Crompton, J. L.

1977 A Systems Model of the Tourist's Destination Selection Decision Process with Particular Reference to the Role of Image and Perceived Constraints. Ph.D. Dissertation, Texas A\&M University, College Station, TX. 1992 Structure of Vacation Destination Choice Sets. Annals of Tourism Research 19:420-434.

D'Amore, L. J. and T. E. Anuza

1986 International Terrorism: Implications and Challenge for Global Tourism. Business Quarterly 11:20-29.

Dillman, D. A.

1978 Mail and Telephone Surveys: The Total Design Method. New York: Wiley. Economist, The 1986a East, West, Home's best 300(7455):28.

1986b Europe Suffers from American Stayaways 299(7447):63-64.

Edgell, Sr., D. L.

1990 International Tourism Policy. New York: Van Nostrand Reinhold. Enders, W. and T. Sandler

1991 Causality Between Transnational Terrorism and Tourism: The Case of Spain. Terrorism 14(1):49-58.

Enders, W., T. Sandler and G. F. Parise

1992 An Econometric Analysis of the Impact of Terrorism on Tourism. Kyklos 45:531-554.

Engel, J. F., D. T. Kollat and R. D. Blackwell

1968 Consumer Behavior. New York: Holt.

Evans, J. R. and B. Berman

1992 Marketing (6th ed.). New York: MacMillan.

Fletcher, M.

1993 Egypt - Is This the Time to Visit? Travel and Leisure 23 (6):60-64.

Gartner, W. C. and J. Shen

1992 The Impact of Tiananmen Square on China's Tourism Image. Journal of Travel Research 30(4):47-52.

Goodrich, J. N.

1978 The Relationship between Preferences for and Perceptions of Vacation Destinations: Application of a

Choice Model. Journal of Travel Research 17(2):8-13.

Goszczynska, M., T. Tyszka and P. Slovic

1991 Risk Perception in Poland: A Comparison With Three Other Countries. Journal of Behavioral Decision Making 4(3):179-193.

$\mathrm{Gu}, \mathrm{Z}$. and T. L. Martin

1992 Terrorism, Seasonality, and International Air Tourist Arrival6 in Central Florida: An Empirical Analysis.

Journal of Travel and Tourism Marketing 1(1):3-15.

Hacker, F. J.

1978 Crusaders, Criminals, Crazies: Terror and Terrorism in Time. New York: Bantam.

Hall, C. M.

1994 Tourism and Politics: Policy, Power and Place. New York: Wiley.

Hall, C. M. and V. O'Sullivan

1996 Tourism, Political Stability and Violence In Tourism, Crime and International Security, Issues, A. Pizam and Y. Mansfeld, eds., pp. 105-121. New York: Wiley. Horner, C. M.

1980 The Facts About Terrorism. Commentary 69(6):40-42.

Hollier, R.

1991 Conflict in the Gulf: Response of the Tourism Industry. Tourism Management 12:2-4.

Howard, J. A.

1963 Marketing Management Analysis and Planning. Homewood, II: Irwin Publishing Co.

1977 Consumer Behavior: Application of Theory. New York: McGraw-Hill. Hurley, J. A.

1988 The Hotels of Rome: Meeting the Marketing Challenge of Terrorism. The Cornell Quarterly 29(1):71-79. Jenkins, B.

1987 The Future Course of International Terrorism In Contemporary Trends in World Terrorism, A. Kurz, ed., pp. 150-159. New York: Praeger. 
1988 Future Trends in International Terrorism In Current Perspectives on International Terrorism, R. O. Slater and M. Stohl, eds., pp. 246-266. London: Macmillan.

Johansson, A. and L. Nyberg

1996 Tourism Conference on Safety and Establishment of a Center. Annals of Tourism Research 23:724-725.

Karber, P. A.

1971 Terrorism as Social Protest. Unpublished paper.

Kahneman, D. and A. Tversky

1979 Prospect Theory: An Analysis of Decision Under Risk. Econometrica 47:263 - 291.

Kent, P.

1991 Understanding Holiday Choices. In The Tourism Industry: An International Analysis, M. T. Sinclair and M. J. Stabler, eds., pp. 165-183. Oxon: CAB International.

Kupperman, R. H. and D. M. Trent

1979 Terrorism. Stanford CT: Hoover Institution Press.

Lai, A. W.

1991 Consumption Situation and Product Knowledge in the Adoption of a New Product. European Journal of Marketing 25(10):55-67.

LaTour, M. S. and S. D. Roberts

1992 Cultural Anchoring and Product Diffusion. Journal of Consumer Marketing 9:29-34.

Lea, J. P.

1996 Tourism, Realpolitik and Development in the South Pacific In Tourism, Crime and International Security Issues, A. Pizam and Y. Mansfeld, eds., pp. 123-142. New York: Wiley.

Lehrman, C. K.

1986 When Fact and Fantasy Collide: Crisis Management in the Travel Industry. Public Relations Journal 42:25-28.

Mansfeld, Y.

1992 From Motivation to Actual Travel. Annals of Tourism Research 19:399- 419.

1996 Wars, Tourism and the "Middle East" Factor In Tourism, Crime and Inter-national Security Issues, A.

Pizam and Y. Mansfeld, eds., pp. 265-278. New York: Wiley.

Mansfeld, Y. and N. Kliot

1996 The Tourism Industry in the Partitioned Island of Cyprus In Tourism, Crime and International Security

Issues, A. Pizam and Y. Mansfeld, eds., pp. 187-202. New York: Wiley.

Mathieson, A. and G. Wall

1982 Tourism: Economic, Physical and Social Impacts. London: Longman.

Mazursky, D.

1989 Past Experience and Future Tourism Decisions. Annals of Tourism Research 16:333-344.

May, W. F.

1974 Terrorism as Strategy and Ecstasy. Social Research 41:277.

Mechitov, A. I. and S. B. Rebrik

1990 Studies of Risk and Safety Perception in USSR. In Contemporary Issues in Decision Making,K.

Borcherding, O. I. Larichev and D. M. Messick, eds., pp. 261-270. Amsterdam: Elsevier.

Mickolus, E. F.

1980 Transnational Terrorism: A Chronology of Events 1968-1979. Westport, CT: Greenwood Press.

Mid Sweden University

1995 Proceedings of Talk at the Top Conference-Research and Travel Trade Conference on Security and

Risks in Travel and Tourism, June, 1995, Ostersund, Sweden: Mid Sweden University.

Midgley, D. F. and G. R. Dowling

1993 A Longitudinal Study of Product Form Innovation: The Interaction Between Predispositions and Social

Messages. Journal of Consumer Research and Social Messages 19:611-625.

Mihalie", T.

1996 Tourism and Warfare. The Case of Slovenia. In Tourism, Crime and Inter-national Security Issues, A.

Pizam and Y. Mansfeld, eds., pp. 232-246. New York: Wiley.

National Travel and Tourism Strategy 
1995 White House Conference on Travel and Tourism, October 30-31, 1995, Washington DC: US Department of State.

Osgood, C. E., G. J. Suci and P. H. Tannenbaum

1957 The Measurement of Meaning. Urbana, IL: University of Illinois Press. Pennings, J. M. and F. Harianto 1992 The Diffusion of Technological Innovation in the Commercial Banking Indus-try. Strategic Management Journal 12:29-46.

Pitts, W. J.

1996 Uprising in Chiapas, Mexico: Zapata Lives: Tourism Falters In Tourism, Crime and International Security Issues,A. Pizam and Y. Mansfeld, eds., pp. 215-227. New York: Wiley.

Pizam, A.

1996 Does Tourism Promote Peace and Understanding Between Unfriendly Nations? In Tourism, Crime and International Security Issues,A. Pizam and Y. Mansfeld, eds., pp. 203-213. New York: Wiley.

Pizam, A. and Y. Mansfeld

1996 Tourism, Crime and International Security Issues. New York: Wiley. Plog, S. C.

1974 Why Destination Areas Rise and Fall in Popularity. The Cornell Quarterly 14(9):55-58.

1990 A Carpenter's Tools: An Answer to Stephen L. J. Smith's Review of Psychocentrism/Allocentrism. Journal of Travel Research 28:43-45.

Poland, J. M.

1988 Understanding Terrorism. Englewood Cliffs NJ: Prentice-Hall.

Redlick, A. S.

1979 The Transnational Flow of Information as a Cause of Terrorism. In Terrorism: Theory and Practice, Y.

Alexander, ed., Boulder CO: Westview Press.

Richter, L. K.

1980 The Political Uses of Tourism: A Philippine Case Study. The Journal of Developing Areas 14:237-257.

1983 Tourism Politics and Political Science: A Case of Not So Benign Neglect. Annals of Tourism Research 10:313-315.

1989 The Politics of Tourism in Asia, Honolulu: University of Hawaii Press. Richter, L. K. and W. L. Waugh, Jr.

1986 Terrorism and Tourism as Logical Companions. Tourism Management 7:230- 238.

Roehl, W. S. and D. R. Fesenmaier

1992 Risk Perceptions and Pleasure Travel: An Exploratory Analysis. Journal of Travel Research 30(4):17-26.

Rogers, R. W.

1975 A Protection Motivation Theory of Fear Appeals and Attitude Change. The Journal of Psychology 91:93114.

Ryan, C.

1993 Crime, Violence, Terrorism and Tourism: An Accidental or Intrinsic Relation-ship? Tourism Management 14(3):173-183.

Sandler, T. and H. E. Lapan

1988 The Calculus of Dissent: An Analysis of Terrorists' Choice of Targets. Synthese 76:244-261.

Schiffman, L. G. and L. L. Kanuk

1991 Consumer Behavior (4th ed.), Englewood Cliffs NJ: Prentice-Hall. Schlagheck, D. M.

1988 International Terrorism. Lexington MA: Lexington Books.

Schmid, A. P. and A. J. Jongman

1988 Political Terrorism. New York: North-Holland.

Schmid, A. P. and J. deGraaf

1982 Violence as Communication: Insurgent Terrorism and the Western News Media. Beverly Hills CA: Sage.

Schwartz, R. D.

1991 Travelers Under Fire: Tourists in the Tibetan Uprising. Annals of Tourism Research 18(4):588-604.

Scott, R.

1988 Managing Crisis in Tourism: A Case Study of Fiji. Travel and Tourism Analyst 6:57-71.

Sharpley, R. and J. Sharpley 
1995 Travel Advice - Security or Politics? In Security and Risks in Travel and Tourism. Proceedings of the Talk at the Top Conference, pp. 168-182. Ostersund, Sweden: Mid-Sweden University.

Smith, V. L.

1996 War and its Tourist Attractions. In Tourism, Crime and International Security Issues, A. Pizam and Y. Mansfeld ed., pp. 247-264. New York: Wiley.

Snepenger, D., K. Meged, M. Snelling and K. Worrall

1990 Information Search Strategies by Destination-Naive Tourists. Journal of Travel Research 29(1):13-16.

Sonmez, S. F.

1994 An Exploratory Analysis of the Influence of Personal Factors on International Vacation Decisions within the Context of Terrorism and/or Political Instability Risk. Unpublished doctoral dissertation. University Park PA: The Pennsylvania State University.

Svyantek, D. J., R. P. Deshon and M. T. Siler

1991 The Illusion of Certainty: A Catastrophe Model of Decision Framing. Current Psychology: Research and Reviews 10:199-209.

Takemura, K.

1992 Effect of Decision Time on Framing of Decision: A Case of Risky Choice Behavior. Psychologia 35(3):180-185.

Teye, V. B.

1986 Liberation Wars and Tourism Development in Africa: The Case of Zambia. Annals of Tourism Research 13:589-608.

1988 Coups D'Etat and African Tourism: A Study of Ghana. Annals of Tourism Research 15:329-356.

The Economist

1990 Ambushing the Peace Bus 314(7641):41-42.

Thornton, T. P.

1968 Terror as a Weapon of Political Agitation. In Internal War,H. Eckstein, ed., New York: Free Press.

Tiegen, K. H., W. Brun and P. Slovic

1988 Societal Risks as Seen by a Norwegian Public. Journal of Behavioral Decision Making 1(2):111-130.

Toman, J.

1991 Developing an International Policy Against Terrorism. in International Terrorism: Policy Implications, S. Flood, ed., pp. 111-128. Chicago: The University of Illinois at Chicago, Office of International Criminal Justice. Tremblay, P.

1989 Pooling International Tourism in Western Europe. Annals of Tourism Research 16(4):477-491.

Tversky, A. and D. Kahneman

1981 The Framing of Decisions and the Psychology of Choice. Science 211:453- 458.

1986 Rational Choice and the Framing of Decisions. Journal of Business 59:251- 278.

US Department of State

1990 Patterns of Global Terrorism: 1989. Washington, DC: US Department of State.

1991 Patterns of Global Terrorism: 1990. Washington, DC: US Department of State.

1992 Patterns of Global Terrorism: 1991. Washington, DC: US Department of State.

1993 Patterns of Global Terrorism: 1992. Washington, DC: US Department of State.

1994 Patterns of Global Terrorism: 1993, Washington, DC: US Department of State.

1995 Patterns of Global Terrorism: 1994. Washington, DC: US Department of State.

1996 Patterns of Global Terrorism: 1995. Washington, DC: US Department of State.

US House of Representatives

1991 The Impact of the Threat of Terrorism and The Recession on the Travel and Tourism Industry. (Serial No.

102-6). Washington, DC: US Government Printing Office.

Um, S. and J. L. Crompton

1990 Attitude Determinants in Tourism Destination Choice. Annals of Tourism Research 17:432-448.

1992 The Roles of Perceived Inhibitors and Facilitators in Pleasure Travel Destination Decisions. Journal of

Travel Research 30(3):18-25.

vanRaaij, W. F. and D. A. Francken

1984 Vacation Decisions, Activities and Satisfactions. Annals of Tourism Research 11:101-112. 


\section{Wahab, S.}

1996 Tourism and Terrorism: Synthesis of the Problem with Emphasis on Egypt In Tourism, Crime and International Security Issues, A. Pizam and Y. Mansfeld, eds., pp. 175-186. New York: Wiley.

1995 Terrorism: A Challenge to Tourism In Security and Risks in Travel and Tourism, Proceedings of Talk at the Top Conference - Research and Travel Trade Conference on Security and Risks in Travel and Tourism Ostersund, Sweden: Mid Sweden University.

Wall, G.

1996 Terrorism and Tourism: An Overview and an Irish Example In Tourism, Crime and International Security Issues, A. Pizam and Y. Mansfeld, eds., pp. 143-158. New York: Wiley.

Watson, F. M.

1976 Political Terrorism: The Threat and the Response. Washington DC: Robert B. Luce Co.

Weber, E. U. and W. P. Bottom

1987 Axiomatic Measures of Perceived Risk: Some Tests and Extensions. Journal of Behavioral Decision

Making 2(2):113-131.

Wieviorka, M.

I994The Making of Terrorism. Chicago, University of Chicago Press. Wilkinson, P.

1976 Political Terrorism. London: Macmillan.

1979 Terrorism and the Liberal State. New York: New York University Press. Woodside, A. G. and D. Sherrell 1977 Traveler Evoked, Inept and Inert Sets of Vacation Destinations. Journal of Travel Research 16(10):14-18. Woodside, A. G. and S. Lysonski

1989 A General Model of Traveler Destination Choice. Journal of Travel Research 27(4):8-14.

WTO

1991 Impact of the Gulf Crisis on International Tourism. World Tourism Organization Special Report. May, 1991. Madrid: WTO. 